UDC 339

\title{
THE EFFECT OF EWOM AND HEDONIC MOTIVATION TOWARD BUYING INTEREST AND DECISION
}

\author{
Azaria Phamendyta Aldaning*, Fauzi Achmad, Wilopo \\ Faculty of Administrative Science, University of Brawijaya, Indonesia \\ *E-mail: dyta1710@yahoo.co.id
}

\begin{abstract}
The availability of information through EWOM in this new wave marketing era is important because it can raise buying interest with the most significant dimension which is expressing positive feelings. Buying interest is a part of consumer behavior in the attitude of consuming, the tendency of the respondents to act before the decision to purchase is actually implemented. Buying interest also occurs on the consumers who browse on online shops. Buying purchase on the online shop is possibly affected by hedonic motivation. This research is aimed to find out, to analyze, and explain the effect of Electronic Word of Mouth toward buying interest, to analyze and explain the effect of hedonic motivation toward buying interest, to analyze and explain the effect of Electronic Word of Mouth toward buying decision, to analyze and explain the effect of hedonic motivation toward buying decision, to analyze and explain the effect of buying interest toward buying decision. The sample used in this research was 116 respondents. This research is an explanatory research using quantitative approach. The measurement used in this research was questionnaire with measurement scale using likert scale. The analysis technique used in this research was Descriptive Analysis and Path Analysis, while hypothesis testing was using $T$ test and standardized beta coefficient. The result of this research shows that according to the objective of the study, there is a positive and significant effect among the variables.
\end{abstract}

\section{KEY WORDS}

EWOM, hedonic motivation, buying interest, buying decision.

Internet has been the reason of the emergence of a new era in marketing that commonly known as new wave marketing where there are more developed competitor products and it needs a good innovation to win the competition and to get noticed by the consumers. Innovation is not only about designing a new better product but also about developing a new business concept and a better strategy. Business strategy is much related to marketing. One of marketing strategies used today is Word of Mouth.

In this internet era, Word of Mouth is now commonly known as Electronic Word of Mouth (EWOM). In social media EWOM becomes an important connector in new wave marketing or in the era where there is a new paradigm of marketing that is horizontal market (Kartajaya, 2009: 18). The existence of this horizontal market allows a connection between the producer and the consumer and/or among the consumers by social media. Social media is widely used because it offers more opportunity of EWOM considering its wide and increasing users.

A report from We Are Social releases several social media which has a huge preference in Indonesia, one of them is instagram. Instagram is a social media which the popularity in Indonesia is continuously increasing, even becomes the biggest instagram community in Asia Pacific and also one of the biggest markets of the total 700 million active users every month around the world (tribunnews.com, 2017). It shows that uploading photos has become a life style in Indonesia and brings Indonesia in the most 100 narcissist country according to Time Magazine (merdeka.com, 2017).

One of marketers that is able to take the opportunity is Canon Indonesia. Besides owning an official account named @canon.indonesia, they also use hash tag \#canonphotoid to create a community in instagram. Canon has a strong line product of digital single reflex lens (DSLR) camera. At its beginning, Canon DSLR is only owned by certain people whose 
profession is photographer, but today there are more people owning this type of camera to show their prestige (www.aristo.id, 2017). Besides showing prestige, the habit of taking and uploading photo with various hash tags is also motivated by the desire to show their existence in the virtual world (duniaprofesional.com, 2015). This is a hedonic motivation which is the motivation based on emotional response, sense of pleasure, dream, and aesthetical consideration (Hirschman \& Holbrook, 1982).

The availability of information through EWOM in this new wave marketing era is important because it can raise buying interest with the most significant dimension which is expressing positive feelings (Sari, 2012). According to Kinnear and Taylor (1995) in Thamrin (2003: 142), buying interest is a part of consumer behavior in the attitude of consuming, the tendency of the respondents to act before the decision to purchase is actually implemented. Buying interest also occurs on the consumers who browse on online shops. Buying interest in online shop can also be motivated by hedonic motivation (Siregar, 2013). It raises a question about the effectiveness of EWOM combined with hedonic motivation toward the consumers buying interest and decision.

New wave marketing is a type of marketing after pseudo marketing and legacy marketing era. Pseudo marketing and legacy marketing is the era of vertical marketing in which the consumer cannot decide anything. New wave marketing a horizontal marketing in which there will be a marketing world with no limitation, the seller will be able to reach the world with no limit so the goods can be sold with higher price while the consumer will be able to choose the best offer to get the best deal (Kartajaya, 2009).

The point of this Horizontal Marketing or New Wave Marketing approach is an active involvement of the consumer in every business phase, from the product development, production process, and its marketing. The components of new wave marketing according to Kartajaya (2009: 160) are Segmentation becomes Communitization, Targeting becomes Confirming, Positioning becomes Clarifying, Differentiation becomes Coding, Product becomes Co-Creation, Price becomes Currency, Place becomes Communal Activation, Selling becomes Commercialization, Brand becomes Character, Service becomes Caring, and Process becomes Collaboration.

Social Media Marketing is a marketing strategy emphasizes on daily conversation with the consumers or among them. Social media marketing takes the concept of daily life such as sharing, rating, reviewing, connecting, collaboration and puts then into a business. Social media marketing makes relationship with the consumers through social media. The relationship will help the company to understand the consumer's need by conversation so the company can produce something regarding the needs of the consumer, sell it, and find out how is consumer's experience about the product through social media conversation.

Word of Mouth (WOM) is the information spread from someone and it is usually used in marketing. WOM in marketing is conducted by making the consumers talking about the offered goods or service (Semovitz, 2012: 3). Word of mouth is usually accepted faster by the consumers because the information is spread by trusted people such as the experts, friends, relatives, and mass media publication. According to Kartajaya (2007: 13) word of mouth is the most effective media to communicate. Silverman (2001: 170) stated the purpose of word of mouth strategy used by companies is to make the consumers tell the positive value of the company to others. According to Thurau, Gwinner, and Gremler (2003), eWOM is reflected into three dimensions as follows:

- Concern for others, it is much related to altruism concept which is the concern for others without any pressure such as keeping someone not to buy goods or services that is considered bad.

- Expressing positive feelings, which is stimulated by positive experiences of the consumers that contributes for the consumer's psychological tension.

- Helping the company, emphasizes on the consumer who wants to help the company as a return for the positive experience of using goods or service of the company.

Motivation can be defined as a pushing power from the inside of individual that forces them to act (Schiffman and Kanuk, 2004:72). That pushing power was originated from a stressful condition as the effect of the needs that cannot be completed. 
The consumer's motivation to purchase positively contributes toward the decision of the consumer to buy goods or services. Buying motivation according to Jim and Kim (2003) are:

- Diversion, a routine or monotone activity that can make people tired so they want to quit their routine a while and do something different like go shopping to department store or mall.

- Socialization, is a type of shopping activity to look for pleasure that is done with friends or relatives in order to interact with others.

- Utilitarian, in a shopping activity, consumer has a closely similar motivation among them, that is to get utility or benefit from that shopping activity.

Hedonic motivation is a motivation of consumer to shop because shopping is a certain pleasure so they do not pay attention to the utility of the goods they have bought (Utami, 2010: 47). According to Hirschman and Holbrook (1982), hedonic motivation is a motivation based on the emotional response, sense pleasure, dream, and consideration. According to Arnold and Reynold (in Utami, 2010:49) hedonic motivation of shopping consists of six principal dimensions as follows:

- Adventure Shopping, that a shopping activity is an adventure, it raises enthusiasm, and people feel like having their own world while shopping.

- Gratification Shopping, that is a shopping activity to relieve stress, and to treat the feeling of unhappy, also as a medium to forget problems and sickness for a while.

- Role Shopping, that is the consumer prefers to shop for other's need rather than for themselves such as giving presents.

- Value Shopping, that is a shopping activity that is done when consumers are searching for department store that offers discount or clearance sale.

- Social Shopping, that is when the consumers think that the pleasure of shopping will be really felt if they spend their time together with their relatives or friends as a socialization activity.

- Idea Shopping, that is when the consumers see a new fashion trend, product, or other innovation and they decide to shop only to get updated.

Simamora (2002:131) argued that interest is something personal and it is related to somebody's attitude. An individual who is interested on a certain object will have power or force to do certain activity in order to get close or to pursue the object. Interest or intention is a desire to behave (Jogianto, 2010: 25). So the existence of interest will raise desire.

Buying interest according to Kotler, Bowen and Makens (1999:156), occurs after a process of alternative evaluation and in the evaluation process someone will make a series of choices about a product he wants to buy based on its label or interest. Howand as cited in Durianto and Liana (2004: 44) stated that buying interest is something related to the consumer's plan to buy certain product with certain amount of it that will be needed for a certain time. Schiffman and Kanuk also explained about the indicators of buying interest, they are: The interest to search more information about the product, considering buying the product, the interest to try the product, the desire to know the product, and the desire to have the product.

Setiadi (2003: 38) explained that buying decision is a process of integrating that combines knowledge attitude to evaluate two or more alternative behavior, and choose one of them. According to Kotler and Armstrong (2008: 181) consumer's buying decision is buying a preferred label from the available alternatives, but two factors can be between buying intention and buying decision. A specific buying decision according to Kotler and Armstrong (2008: 179) consists of following events: identification of the needs, searching for information, alternative evaluation, buying decision, and post-buying behavior.

Buying decision is a combination of several decisions. Kotler (2002: 109) explained that every decision has seven components. Those components are discussed as follows in associated with product purchasing, they are: The decision about the type of the product, the decision about the shape of the product, the decision about the label, the decision about the 
seller, the decision about the amount of the product, the decision about the purchasing time, and the decision about the paying method.

\section{METHODS OF RESEARCH}

This research was an explanatory research with quantitative approach. Singarimbun as cited in Singarimbun and Effendi (Ed. 2008:5) explained that explanatory research is a research that is aimed to explain causal relationship and hypothesis test while quantitative research is to test a theory through its association of several variables, and to make generalization for a population through the sample used. This research explained causal relationship between exogen variable that was E-WOM (X1) and Hedonic Motivation (X2) with variable endogen that was Buying Interest $(Y)$ and Buying Decision $(Z)$. This research was conducted in virtual world that was social media especially instagram. The location was chosen because the data was supporting this research.

The measurement used in this research was questionnaire consisting measurement scale that was likert scale. Meanwhile, the population of this research was unknown. The chosen population was the followers of Canon Indonesia instagram account. The sample of this research was taken from unknown population therefore the sampling method used in this research was Machin and Champbell formula (1987: 89) as follows:

$$
\begin{gathered}
U P^{\prime}=\frac{1}{2} \ln \left(\frac{1+r}{1-r}\right) \\
n=\frac{\left(Z_{1-\alpha}+Z_{1-\beta}\right)^{2}}{\left(U \rho^{\prime}\right)^{2}}+3 \\
U P=\frac{1}{2} \ln \left(\frac{1+r}{1-r}\right)+\frac{r}{2(n-1)}
\end{gathered}
$$

Where:

Ln: $\log -e$ (natural logarithm);

UP: Standardized normal random variable corresponding to particular value of the correlation;

$U P^{\prime}:$ Initial estimate of $U P$;

$\mathrm{n}$ : Sample size;

$\mathrm{Z}_{1-\alpha}:$ The price taken from standard distribution table with determined alpha;

$Z_{1-\beta}$ : The price taken from standard distribution table with desired test authority;

$r$ :Smallest correlation coefficient that expected by the researcher to be significantly detected.

Considering that the smallest $r$ value expected will be derived from this research was $r$ $=30$, and then $\alpha=0,05\left(Z_{1-\alpha}=1,96\right)$ on two ways measurement, $\beta=0,05\left(Z_{1-\beta}=1,645\right)$, it got 116 respondents.

Therefore sampling technique used in this research was purposive sampling. Purposive sampling is a sampling technique used when there is certain consideration for certain purpose (Riduwan, 2010: 20).

Instrument test used in this research was Validity Test and Reliability Test. The validity test used correlation test using SPSS 19 program. Meanwhile, the reliability test was conducted by doing Cronbach Alpha test.

The data analysis used in this research was descriptive analysis to describe the research characteristic by explaining research object that consisted of research location, respondents' characteristic, and also the items distributed from each variable. Path analysis was used to analysis causal relationship happened to the double regression if the dependent variable affected the independent variable not only directly but also indirectly (Retherford, 1993 in Sarwono, 2012). 
This research used standardized t test and beta coefficient to test the hypothesis to find out as if each independent variable had significant effect partially toward the dependent variable.

\section{RESULT AND DISCUSSION}

The respondents of this research are 116 followers of Canon Indonesia instagram account who buy Canon DSLR camera because of the EWOM in instagram, have uploaded any photo to instagram using hash tag \#canonphotoid, do not receive any royalty from Canon DSLR camera, and have willingness to buy Canon DSLR camera again. There are certain characteristics of the respondents of this research including gender, age, latest education level, and occupation.

Based on the gender, the respondents of this research are as follows:

Table 1 - Respondents' characteristics based on gender

\begin{tabular}{|c|c|c|}
\hline Gender & Amount (person) & Persentage (\%) \\
\hline Male & 74 & 63.80 \\
\hline Female & 42 & 36.20 \\
\hline Total & 116 & 100.00 \\
\hline
\end{tabular}

The amount of male respondents is higher because the conversation about electronics and photography such as Canon DSLR camera is more interesting for male. Besides, the size of Canon DSLR camera is a little bit bigger and heavier which is clearly aimed to be used by men. That is why the respondent of this research is dominated by male.

The most respondents' average age is between 23-27 years old which is 52 persons or $44.83 \%$. It is because the interest of respondent of that age to be updated and to follow newest trend and they usually already have income to buy what they need regarding their hobby.

The dominant respondents are students at the amount of 35 persons or $31.17 \%$. It happens because the high level of student's social life and the low level of bustle compared to those who work. Therefore they have more time to socialize in social media.

The respondent with bachelor level of education dominates with the amount of 67 persons or $57.76 \%$. It is because the respondent with that level of education has a high level of intellectuality and anxiety to upgrade their knowledge by using any available facilities including social media.

Variable Descriptive Analysis:

- Electronic Word of Mouth (EWOM), The result of this research shows that the mean of EWOM variable is 4.19 which means the respondents of this research agree with the statements regarding EWOM of Canon DSLR camera.

- Hedonic Motivation. Based on the result, the mean of this second variable is 4.21. It shows that the follower of Canon.Indonesia instagram account agree with the statements regarding hedonic motivation of buying Canon DSLR camera.

- Buying Interest. The result shows that the mean of this indicator is 4.39. It can be seen that the followers of Canon.Indonesia instagram account agree with statements regarding buying interest.

- Buying Decision. Based on the result, the mean of this variable is 4.27 indicating that the followers of Canon.Indonesia instagram account agree with statements regarding buying decision.

Path Analysis Test:

- Coefficient Test of Electronic Word of Mouth Path (X1) toward Buying Interest (Y), according to the counting result it shows that the probability value is 0.000 and $t$ counting is 3.915 then decided that $\mathrm{Ho}$ is rejected (Sig. < 0.05 ). It means that electronic word of mouth (X1) significantly affects buying interest (Y). Coefficient $\beta$ or direct influence value of electronic word of mouth (X1) variable toward buying interest 
$(Y)$ is 0.342 . This coefficient shows that there is a positive effect of EWOM toward buying interest, or in other word, the higher EWOM value the higher buying interest.

- Coefficient Test of Hedonic Motivation Path (X2) toward Buying Interest (Y), the counting result shows the probability value as 0.003 and $t$ counting as 3.083 then decided that $\mathrm{Ho}$ is rejected (Sig. < 0.05). It means that hedonic motivation (X2) significantly affects buying interest $(Y)$. Coefficient $\beta$ or direct influence value of hedonic motivation $(X 2)$ variable toward buying interest $(Y)$ is 0.269 . This coefficient shows that there is a positive effect of hedonic motivation toward buying interest. Therefore in the regression result shows the value of determinant coefficient as 0.257 which means that EWOM and hedonic motivation variables are able to influence buying interest variable for $25.7 \%$ while the rest $74.3 \%$ is influenced by other variables.

- Coefficient Test of Electronic Word of Mouth Path (X1) toward Buying Decision (Z), according to the counting result it shows that the probability value is 0.045 and $t$ counting is 2.032 then decided that $\mathrm{Ho}$ is rejected (Sig. < 0.05). It means that electronic word of mouth (X1) significantly affects buying decision (Z). Coefficient $\beta$ or direct influence value of electronic word of mouth (X1) variable toward buying decision ( $Y Z$ is 0.143 . This coefficient shows that there is a positive effect of EWOM toward buying decision.

- Coefficient Test of Hedonic Motivation Path (X2) toward Buying Decision (Z), the counting result shows the probability value as 0.000 and $t$ counting as 7.851 then decided that $\mathrm{Ho}$ is rejected (Sig. < 0.05). It means that hedonic motivation (X2) significantly affects buying decision $(Z)$. Coefficient $\beta$ or direct influence value of hedonic motivation (X2) variable toward buying decision $(Z)$ is 0.546 . This coefficient shows that there is a positive effect of hedonic motivation toward buying decision.

- Coefficient Test of Buying Interest Path $(Y)$ toward Buying Decision (Z), the counting result shows the probability value as 0.001 and $t$ counting as 3.542 then decided that $\mathrm{Ho}$ is rejected (Sig. < 0.05). It means that buying interest $(Y)$ significantly affects buying decision $(Z)$. Coefficient $\beta$ or direct influence value of buying interest $(Y)$ variable toward buying decision $(Z)$ is 0.252 . This coefficient shows that there is a positive effect of buying interest toward buying decision.

Therefore in the regression result shows the value of determinant coefficient as 0.579 which means that EWOM, hedonic motivation, and buying interest variables are able to influence buying decision variable for $57.9 \%$ while the rest $42.1 \%$ is influenced by other variables

Here is the discussion of research result.

- The Effect of Electronic Word of Mouth toward Buying Interest, according to the research result it shows that the excessive EWOM or picture and conversation about Canon DSLR Camera in instagram will make the followers of Canon.Indonesia instagram account tend to know more about that. EWOM can occur as attention toward buyer candidates such as a recommendation of the appropriate product to use or an experience of using Canon DSLR camera. The existence of EWOM about Canon DSLR camera in instagram will raise buying interest of people who read even they are just interested to find out more information or the desire to have the product. EWOM has a tight correlation with consumer's buying interest as it is stated by Silverman (2001: 170) that the purpose of EWOM strategy is to make the consumers tell the positive value of our company to other consumers so the right word of mouth will bring the consumers to pay attention to the product and make decision.

- The Effect of Hedonic Motivation toward Buying Interest based on the research result it shows that the higher somebody's hedonic motivation toward Canon DSLR camera will increase their buying interest. The research result of hedonic motivation and buying interest agrees with the theory proposed by Duncan in Bose that hedonic motivation will influence the interest of buying, inducting the behavior, and determining the choice while buying goods or service (Duncan in Bose, 2012:566). 
- The Effect of Electronic Word of Mouth toward Buying Decision, the result of the research states that the more and often EWOM or conversation and picture about Canon DSLR camera occur in instagram, the follower of Canon.Indonesia instagram account will read and know more about that and this will influence buying decision of the reader because of the recommendation and positive experience from others about Canon DSLR camera. The research result of EWOM and buying decision agrees with the theory proposed by Kartajaya that Electronic Word of Mouth has a tight correlation with buying decision and mouth-to-mouth marketing is the most effective promotion to influence the consumer to make buying decision (Kartajaya, 2007: 183).

- The Effect of Hedonic Motivation toward Buying Decision, based on the research result it shows that the existence of somebody's hedonic motivation for Canon DSLR camera, in this case is the followers of Canon.Indonesia Instagram account, will influence the buying decision making of the goods. The decision can be caused by a desire to raise prestige or just to follow recent trends. The research result about hedonic motivation toward buying decision agrees with the theory such as hedonic motivation will force someone to act including to make buying decision (Schiffman and Kanuk, 2004:72).

- The Effect of Buying Interest toward Buying Decision, according to research result it is stated that the higher somebody's buying interest toward Canon DSLR camera, the easier for them to make buying decision. The research result about the effect of buying interest and buying decision agrees with the theory which states that buying interest is a part of consumer's behavior component in consuming behavior, the tendency of the respondent to act before buying decision has been really implied (Kinnear and Taylor, 2003:142).

- The Effect of Electronic Word of Mouth toward Buying Decision through Buying Interest, based on the research result showing that EWOM or conversation and picture about Canon DSLR camera in instagram will make the followers of Canon.Indonesia instagram account tend to know more about the conversation. The conversation can be occur as attention toward buyer candidates such as a recommendation of the appropriate product to use or an experience of using Canon DSLR camera.

- The Effect of Hedonic Motivation toward Buying Decision through Buying Interest, the result of the research shows that the existence of hedonic motivation for Canon DSLR camera such as the desire to buy when there is special promo or just to follow the recent trend will make someone, in this case is the followers of Canon.Indonesia instagram account, to be interested to buy the camera. Motivation can be defined as pushing power from inside of individual that forces them to do something (Schiffman and Kanuk, 2004:72).

\section{CONCLUSION}

Electronic word of mouth (X1) is positively and significantly affects buying interest $(\mathrm{Y})$ which means when there are more conversations or pictures about Canon DSLR camera, the follower of Canon.Indonesia instagram account will know more about that information and affect their buying interest toward the camera.

Hedonic motivation (X2) has a positive and significant influence toward buying interest $(Y)$. it means that the higher hedonic motivation of the follower of Canon.Indonesia toward Canon DSLR camera, it will raise buying interest of the followers of Canon. Indonesia toward Canon DSLR camera.

Electronic word of mouth (X1) has a positive and significant influence toward buying decision $(Z)$ which means that the more conversations and pictures of Canon DSLR camera showed in instagram, the more information will be gained by the follower of Canon.Indonesia instagram account and it affects the onset of the followers' buying decision toward the camera. 
Hedonic motivation (X2) positively and significantly affects buying interest ( $Z$ ) which means that when hedonic motivation of the follower of Canon.Indonesia instagram account toward Canon DSLR camera is increased, it will raise the followers' buying decision toward the camera.

Buying interest $(Y)$ has a positive and significant effect toward buying decision ( $\mathrm{Z})$. It means that when buying interest of the follower of Canon.Indonesia instagram account toward Canon DSLR camera is increased, it will raise buying decision toward the product.

Buying interest $(Y)$ has been proven to be intervening variable in the correlation of electronic word of mouth (X1) toward buying decision (Z), it means that buying interest is a variable that can connect electronic word of mouth variable with buying decision.

Buying interest $(Y)$ has been proven to be intervening variable in the correlation of hedonic motivation (X2) toward buying decision (Z), which means that buying interest is a variable that can act as connector of hedonic motivation variable with buying decision.

Electronic Word of Mouth (EWOM) of a product should be developed considering that the world is turning to the era of digital and social media. It will be better for the company to add more Instagram admin and employing them in shifts so there will be more improved EWOM later. The next researcher is expected to observe other variables to get more various results that are possible to influence buying interest and decision. The next researcher is also expected to improve this research by analyzing other variables to find out the factors that influence somebody's buying decision.

\section{REFERENCES}

1. Durianto, D., \& Cicilia, L. (2004). Analisis Efektifitas Iklan Televisi Softener. Soft \& Fresh di Jakarta dan Sekitarnya dengan Menggunakan Consumer. Jurnal Institut Bisnis dan Informatika Indonesia Volume, 11(2004), 35-55.

2. Holbrook, M. B. (1982). The Experiential Aspects of Consumption: Consumer Fantasies, Feelings, and Fun.The Journal of Consumer Research, 9(2), 132-140.

3. Jin, B., \& Jay, O. K. A. (2003). Typology of Korean Discount Shoppers: Shopping Motives, Store Attributes, and Outcomes. International Journal of Service Industry Management, 14(4), 396-419.

4. Jogiyanto. (2008). Metodologi Penelitian Sistem Informasi. Yogyakarta: Andi

5. Kartajaya. (2009). New Wave Marketing, The World is Still. Round The Market is Already Flat. Jakarta : Gramedia.

6. Kinnear, T.C. (2003). Riset Pemasaran (3rd ed). Translated by Thamrin. Erlangga.

7. Kotler, P., Bowen., \& Makens. (1999). Marketing for Hospitality and Tourism (2nd Ed). New Jersey: Prentice Hall Inc.

8. Kotler, P., \& Garry, A. (2008). Prinsip-prinsip Pemasaran (12th Ed). Translated by Damos Sihombing. Jakarta: Erlangga.

9. Sari, V. M. (2012). Pengaruh Electronic Word Of Mouth (eWOM) Di Social Media Twitter Terhadap Minat Beli Konsumen. Jakarta. Universitas Indonesia. (Unpublished thesis).

10. Sarwono, J. (2012). Path Analysis dengan SPSS. Jakarta: PT. Elexmedia Komputindo.

11. Schiffman, L., \& Lesslie, L. K. (2004). Perilaku Konsumen. Translated by Zoelkifli Kasip. Jakarta: Prentice Hall

12. Sernovitz, A. (2012). Word of Mouth Marketing. Austin: Greenleaf Book Group Press.

13. Setiadi, N.J. (2003). Perilaku Konsumen. Jakarta: Kencana.

14. Simamora, B. (2002). Panduan Riset Perilaku Konsumen. Surabaya: PustakaUtama

15. Singarimbun, M., 2008. Metode Penelitian Survai. Jakarta: Pustaka LP3ES Indonesia.

16. Siregar, E. V., \& Citra, K. D. (2015). Pengaruh Hedonic Shopping Motivation Terhadap Impulse Buying Pada Toko Online (Studi Pada Berrybenka.Com). Journal e-Proceeding of Management, 2(1), 635-642

17. Thurau, H. T., et al. (2004). Electronic Word-of-Mouth via Consumer-Opinion Platforms: What Motivates Consumer to Articulate Themselves on the Internet. Journal of Interactive Marketing, 18(1), 38-52

18. Utami, C. W. (2010). Manajemen Ritel. Jakarta: Salemba Empat. 